\title{
Erratum: Reappraising the effects of artemisinin on the ATPase activity of PfATP6 and SERCA1a E255L expressed in Xenopus laevis oocytes
}

Stéphanie David-Bosne, Michael Voldsgaard Clausen, Hanne Poulsen, Jesper Vuust Møller, Poul Nissen \& Marc le Maire Nat. Struct. Mol. Biol. 23, 1-2 (2016); published online 6 January 2016; corrected after print 13 January 2016

In the version of this article initially published, the position of the mutation reported in ref. 7 was incorrectly described as L236; it should be L263. In addition, in the HTML version of this article originally published, the concentration of artemisinin was given incorrectly as $50 \mathrm{mM}$ instead of $50 \mu \mathrm{M}$; the PDF version and the legend text were correct. The errors have been corrected in the PDF and HTML versions of the article.

\section{Erratum: Exploiting the exploiter: a viral inhibitor stabilizes TAP for cryo-EM}

\section{Rutger D Luteijn \& Emmanuel J H J Wiertz}

Nat. Struct. Mol. Biol. 23, 95-97 (2016); published online 3 February 2016; corrected after print 11 February 2016

In the version of this article initially published, the name of the first author in ref. 1 was misspelled as Oldman. The correct name is Oldham. The error has been corrected in the HTML and PDF versions of the article. 